\title{
The Early History of the Lord's Supper
}

\author{
Henk Jan de Jonge (Leiden Unrversity)
}

\section{Shape and Function of the Community Supper in Corinth}

As an historical phenomenon the Lord's Supper becomes perceptible for the first time in the first epistle of Paul to the Cornnthians shortly after the middle of the first century C.E. ${ }^{1}$ The Corinthian community meal was a deipnon (1 Cor 11:20, 21), that is to say, a supper, the main meal at the end of the day. It was followed by a community meeting, for which 1 Cor $12-14$ contains directions. ${ }^{2}$ Apparently, this supper and meeting took place every Sunday (1 Cor 16:2). Since Sunday was a working day, the meal could only commence in the evening (or in the late afternoon at the earliest).

"The Lord's Supper" (11:20) was a real meal; it was certanly meant to satısfy the partıcipants' hunger. But it was also more than just an ordinary meal, it established the unity of the congregation: "Because there is one loaf, we, though many, are one body; for it is one loaf of which we all partake" (10:17). According to Paul, this unity came about through the participants' drinking from the cup and eating the bread and their recognition that, in doing this, they became one body with Christ (10:14-17). This recognition, that 1s, this sacramental interpretation of the meal, may have been formulated in the blessings with which the meal was opened. In short, the Lord's Supper was a real as well as a sacramental meal.

The number of participants in this meal may be est1mated at 35 or somewhat more. ${ }^{3}$ They assembled in a room of the private house of a well-to-do member of the communty. This person (possibly Gaus,

\footnotetext{
'I wish to thank the participants in the research progran on "Interaction between Jews, Christians, and Gentules in the Graeco-Roman penod" of the Leiden Institute for the Study of Religions (LISOR), and especially Matthys J de Jong, Professor M de Jonge, and dr Johan S Vos, for their critical comments on an earlier version of this paper

${ }^{2} \mathrm{M}$ Klinghardt, Gemeinschaftsmahl und Mahlgemeinschaft Soziologie und Liturgie fruhchrstlicher Mahlfetern (TANZ 13, Tubingen Francke, 1996), 333-71

${ }^{3}$ Klinghardt, Gemeinschaftsmahl und Mahlgemetnschaft, 324-25
} 
Rom 16:23; cf. 1 Cor 1:14) may also have acted as the host and leader of the gathering. Alternatively, the meal may have taken place in some hall or room rented for the weekly gatherng. The participants ate reclining on couches. In the case of group suppers in the GraecoRoman world, the couches were normally placed so as to form three sides of a square or a triclnium. This may also have been the case in the Christian community of Corinth. Tertullian still speaks of the Lord's Supper as "the triclinium of the Christians." Food was served from the open space between the couches and put on low tables within the participants' reach.

The participants brought their own food. In principle, the idea was that the poorer members of the community, the "have-nots" (11:22), could consume the food which the more well-to-do brought with them but did not consume. This created the koinonia of the community and gave the meal the function of a charity meal. This is why it was also called agape (Jude 12; Ignatius, Smyrn. 7:1; 8:2; etc.).

The abuse which Paul wanted to correct among the Cornthians stemmed from their fallure to share their food with each other Instead of gathering in all the food before the meal started and then dividing it in equal portions among the participants, each of them ${ }^{5}$ only ate the portion which he or she had brought with him (her). Thus, each participant "took his own supper" (11:21). ${ }^{6}$ The result was that the wealthier members ate larger and better portions than the poorer members. This inequity gave nse to divisions within the community. The Cornthian abuse also confirmed the social differences between the members of the community instead of cancelling and abolishing them. In this way the Lord's Supper missed its mark.

The purpose of the community meal was the realization of the communion (koinonia, including equality, fellowship, solidanty, and brotherhood) which the members of the congregation felt they missed so badly in the outside world. The Lord's Supper was intended to unite "Jews and gentiles, slaves and free men" (12:13). As a result of the abuses in Cornth, however, the Lord's Supper had exactly the opposite effect. The individualistic and selfish behavior of the participants had a devastating effect on the unity and coherence of the community; it caused divisions. The community fell into sharply

\footnotetext{
${ }^{4}$ Tertullian, Apol 3915

'Or certain groups among them, for mnstance, the members of certain households

${ }^{6}$ In 1 Cor 1121 prolambanes is probably equivalent to lambanel, Klinghardt, Gemernschaftsmahl und Mahlgemeinschaft, 288-89
} 
divided groups (11 18). ${ }^{7}$ Thus Paul can say: "Your meetings tend to do more harm than good" (11:17). Not only the unity of the community suffered by the misbehavior of some participants, also individual members of the community were harmed by 1 . The harm done to the community manifested itself, according to Paul, in illness and deaths in the Cornthran church. The result of the damage done to the community is that "many of you are feeble and sick, and a number have died" (11:30). Paul goes on to warn those who cannot content themselves with the equally divided portions assigned to them at the community supper, "to eat at home, so that in meeting together you may not fall under judgement" (11:34).

In order to correct the Cormthian abuses, Paul adduces the tradition concerning the institution of the Lord's Supper (1 Cor 11:23-25). This is a pre-Pauline tradition, which is also utilized by Mark (14.22-25). With the help of this tradition Paul interprets the koinonia of the community as brought about by the death of Christ. Paul quotes this tradition in order to demonstrate the unacceptability of the Connthian practice. He claims (11:23) that he had already used the same tradition to explain the meaning of the Lord's Supper durng his first stay in Corinth. This may be correct, but there is no compelling reason to assume that the tradition concerning the institution of the Lord's Supper by Jesus formed part of the Corinthian eucharistic rite. ${ }^{8}$ True, the blessings with which the Lord's Supper in Connth started may have expressed now and then the idea that the eating of the bread and the drinking of the cup brought about the komonia of the community But this need not always have been the case, and even if it happened, this does not imply the recitation of the institution narrative. ${ }^{9}$

The fact that Paul chose to castigate the Corinthians' misbehavior with the help of the tradition concerning Jesus' institution of the

${ }^{7}$ These groups were nether the parties mentioned in 1 Cor $110-12$, nor the ethmic and social groups mentioned in 1213 (Jews, gentiles, slaves, and free men), but groups belonging to different households or families People of one household refused to share the food they had brought with them with people of other households

${ }^{8}$ I will use the terms "the Lord's Supper" and "euchanst" as interchangeable synonyms without any denommational connotation

${ }^{9}$ According to G A M Rouwhorst, De vienng van de eucharistie in de vroege kerk (Utrecht Katholieke Theologische Unversiteit, 1992), 8-18, the institution narrative was not recited in the type of euchanst reflected in 1 Cor 10 16-17, Luke 22 15-19a (Western text), and Did 9-10 In my view, however, it was not even recited at the eucharist referred to by Paul in 1 Cor 11 Nor am I convinced that 1 Cor 10, Luke 22, and Did 9-10 reflect a common tradition of the celebration of the euchanst which is different from that in 1 Cor 11 
Christian community Supper, shows that the Corinthians were not, or not always, alive to the theological implications which that tradition had in Paul's opinion. The Connthians were no doubt aware that the Lord's Supper had to establish the unity of the congregation and its community with Christ, but they were obviously less familiar with the Idea that the bread and the wine represented Jesus' body and blood. Nor were they imbued with Paul's idea that the Lord's Supper represented the death and resurrection of Jesus, wath whom the participants in the meal united by eating the bread and drinking the wine. In the Corinthians' opinion, the communion which the participants attained with one another and with Christ came about by their eating the same loaf and drinking one cup. In order to establish the community, the loaf and the cup did not need to be interpreted as the body and blood of Christ. Both Paul and the Corinthians knew that the same applied to the food which was served at pagan sacrificial meals. In order to make those who partook in such meals partners with one another and with the god at issue, it was by no means necessary for the food to be interpreted as that god's body (1 Cor 10:20). Thus, the Corinthians' view of the Lord's Supper seems to have been considerdbly less sophisticated than that of Paul. This relatively simple view of the community meal surfaces several tumes in Paul as well. Sec for instance 1 Cor 10:1-4. As the people of God, the Israelites had the prefigurations of the Church's sacraments, baptism as well as the Lord's Supper. The partaking in the Supper brought about the unity among the Israelites, owing to the fact that "they all ate the same supernatural food (the manna) and all drank the same supernatural drink (from the rock)." Thus, the unity of the people was established by their eating the same food and their drinking the same drink. Here food and drink do not stand for Jesus' body and blood, nor does the meal represent Jesus' death. The view of the meal here is a simple, un-Pauline one. The same is true for 1 Cor 10:17. Here the unity of those who participate in the Lord's Supper comes about by their eating the same loaf: "Because there is one loaf, we, many as we are, are one body: for it is one loaf of which we all partake." In the sober view of the Lord's Supper reflected in 1 Cor 10:3-4a and 17, bread and wine are not interpreted as Jesus' body and blood, nor the meal as a representation of Jesus' death. These latter interpretations are only put forward by Paul in 11:23-24 in order to criticize and mend the Corinthians abuses. Paul's claim that he has taught them these interpretations fivc years ago may be right, but judging by their behavior at the community meal, they had forgotten most of it. Meanwhile their view 
of the Lord's Supper had been a simpler one than the one Paul had taught them and sets out again in 1 Cor 11:23-32.

Paul agrees that the komonia, which was the purpose of the Lord's Supper, was attained through the consumption of bread and winc (10 16-17) But he takes the bread and the wine to stand for Jesus' body and blood (11:24-25). The consumption of the bread and the wine could thus be taken to portray, or rather (as Paul says) to "proclaim," the death of Jesus (11:26). Apparently, Paul believed that the death of Jesus (and especially God's merciful reaction to this death, to which I will return below) had united Jesus and his followers into one body, "the body of Christ." 1 "Consequently, since the Lord's Supper was a portrayal (or representation, or proclamation) of Jesus' death, it had to make manifest the unity of Christ's body. Paul argues that, since the Corinthians' behavior at the Lord's Supper enta1s dissensions and divisions in the congregation, they are obviously going about it in the wrong way. Only if the participants' behavior at the Lord's Supper reflects the unity of the Lord's body, can the community meal bring about the komonia that is its goal: komonia with Christ and with one another.

Paul quotes the tradition concerning the institution of the Lord's Supper with the obvious intention to admonish the Cormthians and to urge them to behave more socially-minded It is less clear, though, why he tries to attain his end by the express mention of the theme of

"In the Graeco-Roman world the tern "body" (soma, corpus) was a very current metaphor for any "whole" composed of parts (people or things) which function together as a untty, e g, the state, see Livy 132 Plutarch, for instance, designates the assembly of a city-state, the ekklesia, as a "body" (soma) and points out that this body is conposed of separate bodies, the individual persons "Is a single body in this world not often composed of several separate bodies, as, for instance, a city assembly, an army, or a dance group" (De defectu oraculonum 426A) In a smular way, Paul can speak of the Church "Many as we are, we are one "body" (soma)" (1 Cor 10 17) However, when Paul designates the Christian congregation as "the body of Christ," the phrase "body of Christ" is clearly more than just a metaphor, it refers to a concrete reality In Paul's opmion the congregation is really the body of Chnst The reality of this "body" of Christ becomes clear 1 1 1 Cor 6 12-20, where Paul argues that someone's union with the body of Christ (in the Church) excludes his union with a prostitute Simularly, in 1 Cor 10 14-21 Paul insists that the unity of Chnst's body presented in the Supper is exclusive "You cannot dnnk the cup of the Lord and the cup of demons, you cannot share the table of the Lord and the table of the demons "Many Connthin Chnstrans become 1 ll and die as a result of the divisions in the "body of Christ," $1 \mathrm{e}$, the Christ1an communty (1 Cor $1129-30$ ) Obviously, for Paul "the body of Christ" is a concrete entuty, not only a metaphor See W A Mecks, The First Urban Chnstinns The Socral World of the Apostle Paul (New Haven Yale University Press, 1983), 159-60 
Jesus' death (11:26). He could have argued much more directly For instance: bread and wine stand for Jesus' body (in a Christological sense); in eating and dnnking this "body," one becomes one body with Christ (in an ecclesiological sense); one must not divide the body of Christ; so in eating the Lord's Supper, one has to avoid dissensions, otherwise one divides the body of Christ. In this line of reasoning, the subject of Jesus' death does not even need to be raised. Why then does Paul say that in eating the bread and drinking the wine of the Lord's Supper, "you proclaim the death of the Lord"? Why does he introduce the theme of Jesus' death?

One part of the answer must certainly be that, traditionally, the narrative of the institution of the Lord's Supper referred to Jesus' death already. This is clear from the rudimentary "surrender formula" (Dahingabeformel) transmitted in Mark's version of the story: "This is my blood . . . , shed for many" (14:24) as well as in Paul's version in 1 Cor: "This is my body, for you" (11:24). But this is only part of the answer.

Another part of the answer must be that Paul was strongly preoccupied with the idea that the Christian community owed its very existence to the participation of the believers in the death and resurrection of Christ. ${ }^{11}$ In agreement with earlier Christian tradition, Paul considered Jesus' death an event which had provoked God's grace, not only towards Jesus (whom God vindicated by raising him from the dead), but also towards Jesus' followers, whom God released from their sins, restored in his favor, and with whom God entered into a new covenant (all this is what Paul also calls justification and reconcilation). In his reaction to Jesus' death, God treated Jesus and his followers as members of one corporate entity: on the one hand, he vindicated Jesus, and on the other hand, he justified those who remained faithful to Jesus after his death. ${ }^{12}$ Thus, in responding to Jesus'

\footnotetext{
"It is true that when Paul interprets the eating of the bread and the drunking of the cup as a proclaniation of the death of the Lord (1 Cor 1126 ), he does not add "and of his resurrection "Yet this is what he had in mind, for the fact that he adds "untul he comes" (1 Cor 1126 ) shows that in his view the one whose death is proclanmed is the Lord who is now living with God in heaven, from where he will come agan This understanding of the Lord's Supper is made explicit in the eucharistic prayer in Hippolytus, Traditio apostolica 4 "Memores igitur mortis et resurrectionis eius, offerumus tibı panem et calicem, gratıas tibi agentes "Cf Cypnan, Ep 63162 "Nos autem restrrectionem Domuni mane celebramus"

${ }^{12}$ See my artıcle "De plaats van de verzoenung in de vroegchristelıjke theologie," in Verzoening of koninkrijk Over de priontest in de verkondiging (ed A A van Houwclungen et al , Baarn Callenbach, 1998), 63-88
} 
death, God confirmed the corporate unity of Jesus and his followers. Therefore, Paul can take the death of Jesus as an event of fundamental significance with regard to the unity of Christ and his followers. Consequently, when Paul wanted to urge the Corinthian Christians to adopt a more socially-minded behavior, it was quite natural for him to take the theme of Jesus' death as a reference point: this death was the fundament of the post-Easter church; that is, of the unity of Christ and his community.

Let us now look at the order of the ritual in Corinth. To a certain extent it must have conformed to the one recorded in the tradition concerning the institution of the Last Supper. Otherwise, Paul could not have adduced the tradition of the Last Supper as an analogy. This means that the Lord's Supper must have started with

(a) a benediction over the bread (1 Cor 11:23), or rather with benedictions over both wine and bread (1 Cor 10:16; cf. Luke 22:17; Did. 9:2-3). The benedictions were pronounced by a leading member of the community. As I pointed out before, these prayers may have given expression to the participants' belief that, in drinking the cup and eating the bread, they became one body with Christ. But since there is no reason to suppose that the benedictions had already taken on a fixed shape in the fifties of the first century C.E., it cannot be taken for granted that the introductory benedictions always contained a theological interpretation of the meal.

(b) Subsequently, the meal took place. It deserves to be observed that the bread not only served as food, but also as a means to handle other dishes, such as vegetables, meat, fowl, fish, cheese, honey, olives, and herbs, and to bring these to one's mouth. From the fact that only bread is mentioned ( 1 Cor 10:16-17;11:26), it must not be inferred that bread was the only food which was eaten.

(c) At the end of the meal, that is, after supper, a benediction was pronounced over the wine (1 Cor 11:25; cf. the direction in Did. 10:1: "when all have partaken sufficiently," "after being filled, give thanks in these words: ..." ").

(d) Afterwards, those present stayed together for the exchange of instruction $(14: 6,26)$, revelations $(14: 6,26)$, prophecies $(14: 1,3)$, psalms $(14: 26)$, ecstatic utterances $(14: 3,4,26)$, interpretations of such utterances $(14: 26,28-30)$, singing and praying (14:14-15), and for praising and thanking God (14:16-17).

It should be noticed that part (d) took place on the same evening as the supper itself. In other words, the whole of 1 Cor 11:17-14:40 deals with one and no more than one periodical meeting of the congregation. This is clear from the fact that Paul refers to this meeting in the same words at the beginning (11:17-18) and at the end (14:23- 
26) of the passage mentioned without distinguishing between different meetings. In 11:17 he says "you come together (synerchesthe) to the detriment of the community." In 11:18: "when you come together as a congregation (synerchomenon hymon en ekklesia)..." In chapter 14 he still uses the same expressions. In 14:23 he says "So if the whole congregation comes together ..." (synelther he ekklesia) and in 14:26: "when you come together . . " (synerchesthe). ${ }^{13}$ The passage 14:26-40 is the conclusion of chapters 12-14. Since there is no indication that Paul's attention shifts from one type of meeting (the Lord's supper, discussed in ch. 11) to another type of meeting at the beginning of ch. 12 , the "coming together" (synerchesthai) of ch. 11 must refer to the same meeting as that of ch. 14, except that 11:17-34 treats the first part of the meeting, that is, the meal proper, whereas chapters 12-14 deal with the second part of the meeting, that is, the session employed for singing, praying, prophecy, glossolalia, and other spiritual gifts.

The question can be raised whether part (d) followed or preceded the meal $(\mathrm{a}-\mathrm{c})$. Judging by Mark 14:26, where the singing follows the supper, and the order in which Paul discusses the supper (1 Cor 11) and the spiritual gifts (1 Cor 12-14), the meal must have been the first part of the meeting and the session devoted to the spiritual gifts the second part.

The purpose of this second part of the meeting was the strengthening, confirmation, and consolidation of the spiritual solidarity (koinonia) among the members of the congregation, or in Paul's words, "the building up of the church" $(14: 12,26)$.

It is of great importance to realuze that the second part of the gathering as depicted by Paul corresponded to the symposium which, in the Hellenistic world, normally followed the group supper of voluntary societies. After supper, wine was served and the evening was spent in conversation and conviviality. ${ }^{14}$ The guests might entertain each other

${ }^{13}$ In 1426 the New English Bible translates "when you meet for worshp," rightly so, for the meeting meant in ch 14 is the same as that of $\mathrm{ch} 11$

${ }^{14} \mathrm{E}$ Ferguson, Backgrounds of Early Chnstianity (2nd ed, Grand Rapids, Mich Eerdmans, 1993), 96-98 A case in point is the banquet described in Petronius, Cena Trimalchions, where the banquet proper is depicted in the chapters $31-69$ and the after-supper entertainment in chapters 70-78 Another example is Lucian, Convivum 6-47 In this case the transition between the detpnon (paragraphs 6-14, the word deipnon occurs in the paragraphs 1,2 , and 5), and the sympostum (paragraphs $15-47$, the word occurs in 47 and 48) is gradual and smooth, but from paragraph 15 onward the cup is going round, there are toasts, conversations, and speeches, someone recites verses, someone else reads aloud from a book, a clown dances and makes jokes, etc The same twofold structure of the group meal is mirrored in John's account of the Last 
by singing songs, reciting recent or older literary compositions, playing games, and dancing. ${ }^{15}$ The early Christians naturally had their own repertoire of interventions to contribute to this second part of the session (prayers, hymns, prophecies, etc.). Structurally, however, their after-supper gathering is the exact equivalent of the after-dinner session which followed the periodical banquet of many clubs and societies in the Graeco-Roman world, both gentule and Jewish

Other Testimonies for the Celebration of the Lord's Supper in the First and Early Second Centuries

(I) Mark was familiar with the rite of the Christian community supper: 10:38 and 14:36 presuppose the exustence of the Lord's Supper and Mark's acquaintance with it.

In Mark 10:38 Jesus asks: "Can you drınk the cup that I drink, or be baptized with the baptism I am baptized with?" In this context drinking the cup and being baptized are images for the passion which Jesus is to undergo. But the very selection and combination of the images of "drinking" and "being baptized" make it clear that Mark is thinking here of the two constitutive rites of the Church, the Lord's supper and baptism. In 14:36 Jesus says: "Let this cup pass from me." Many exegetes have explained "this cup" by referring to the Old Testament image of "the cup (or scale) of God's wrath." But the idea of God's wrath does not fit in Mark's context. It is more probable that the starting-point of Mark's imagery here is the cup of the Lord's Supper. In the tradition concerning Jesus' Last Supper (used by Mark in the preceding pericope) this cup was taken as a symbol of Jesus' death (14:24). Hence, Mark could designate the fate Jesus faced in Gethsemane, that 1s, his suffering and death, as "this cup "In bref, Mark 10:38 and 14:36 are evidence that Mark was familiar with the Lord's Supper.

Mark's story of the Last Supper (14:22-26a), however, does not provide unambiguous evidence for Mark's knowledge of the weekly

Supper John 13 2-30 describes the supper proper (2 detpnon ginomenou, 4 deipnou, 12 anepesen palin) and 13 31-17 26 the after-supper session with instruction, conversation, speeches, admontions, and prayer

${ }^{15}$ Dancing after supper is widely attested, see, e g, Philo's account of the Pannychis of the Therapeutae (Contempl 83-85), Petronius' depiction of the dinner given by Tnmalchıo "Ian coeperat Fortunata velle saltare" (Cena Trimalchons 709), and Mark's story about the birthday banquet given by Herod Antipas "Her (that is, Herodias') daughter came in and danced" (6 21-22) 
rite of the Lord's Supper. The passage does not contain the institution words spoken by Jesus. It cannot be ascertained, therefore, whether Mark borrowed this tradition from a eucharistic context (as is generally assumed). It may also have reached him as a story about the last hours that Jesus spent with his disciples. This means that, in and of itself, Mark's account of the Last Supper does not prove that Mark was acquainted with the eucharist.

On the other hand, Mark's narrative of the Last Supper (14:22-26a), including Jesus' words about the bread and the wine, clearly derives from the same tradition as Paul's account of Jesus' Last Supper in 1 Cor 11 23-25. Mark 14.22-26a and 1 Cor 11:23-25 reflect a common earlier tradition. This common tradition underlying Mark 14:22-26a and 1 Cor 11:23-25 does not reach back to Jesus himself. It has probably onginated as a clarification of the Christian rite of the Lord's Supper or eucharist, for it looks very much like a post-Easter aetiology of that rite. The equations of the bread with Jesus' body and the wine with Jesus' blood; the phrase "for you" (1 Cor 11:24) or "for many" (Mark 14:24), which probably implies a soteriological interpretation of Jesus' death; the suggestion of the nearness of Jesus' end in his words "I will not drunk from the fruit of the vine unt1l that day when I drink it new in the kingdom of God" (Mark 14:25) and "Do this as a memorial of me" (1 Cor 11:25); all this makes it difficult to believe that the story preserves pre-Easter tradition. "Further reasons for which it is difficult to assume that the common tradition underlying Mark 14:22-26a and

${ }^{16}$ Still less plausible is the view that the Lord's Supper goes back to a Passover meal which Jesus would have had with his disciples on the eve of his death The Passover meal mentioned in Mark 14 is clearly a late and secondary feature in the tradition concerning Jesus' passion (a) Paul does not yet say that Jesus' last supper was a Passover meal (b) In Mark 14 all references to Passover belong to Mark's redaction, to begin with 141 (c) The supper of Mark 14 22-25 is not depicted as a Passover meal (d) In 14 53-151 (the meeting of the complete Sanhedrnn on Thursday evenung, their nightly session, and the handing over of Jesus to Pilate on Friday morning) Mark seems to have forgotten that the members of the Sanhedrin had to celebrate the Festival of Passover and Unleavened Bread (e) The same is true for 1542 , for whatever Joseph of Arumathea, member of the Sanhednn, wished to do before the Sabbath because he was not allowed to do it on the Sabbath, was equally offensive on the first full day of the Passover festival (Friday) until sunset As to John, his gospel is literally dependent on Mark and Luke, he is no independent witness for Jesus' chronology Furthermore, I take John 64 "Passover was near" to mean that the season allowed Jesus, the disciples, and the crowd to go up the hill-side (6 3), to sit down there on the "grass" (6 10), and to have a meal in the open arr $(610-13)$ The supposition that the mention of Passover here has to do with alleged euchanstic overtones of the story of the feeding of the five thousand is superfluous 
1 Cor 11:23-25 goes back to a histoncal institution of the Lord's Supper by Jesus himself include the following. (1) If Jesus instituted the Lord's Supper, how can one account for the fact that the euchanstic prayers transmitted in $D_{1} d$. 9-10 preserve no trace of this institution? (2) The institution word transmitted in 1 Cor 11:25 "Whenever you drink it, do this as a memorial of me" logically presupposes the existence of the custom of drinking the cup. The word only adds the instruction to drink it in memory of Jesus. The institution word must be later, therefore, than the ongin of the Lord's Supper. In brief, the tradition concerning the institution of the periodical community meal by Jesus seems to have originated as an attempt to trace the origin of the meal back to Jesus. ${ }^{17}$ In a similar manner the institution of the nite of baptism was attributed to Jesus in Matt 28:19.

It should be borne in mind that in the Hellenistic world many of those who adhered to a certain religious institution or cult liked to trace the origin of this institution or cult to an illustrious founder, preferably a god or a hero. Let me illustrate this with two random examples from Pausanias' description of Greece (second century C.E.). In Argolis Pausanias visited the sanctuary of the goddess Eileithyia near Anaktes. According to local tradition, this sanctuary was founded and consecrated by no less a person than Helen, daughter of Zeus and the future wife of Menelaus of Sparta. Before she married Menelaus, she was raped by Theseus. After she had been rescued by her brothers Castor and Polydeuces, she founded the temple of Ellesthyra (Pausanias, Descr 2.22.6-7). According to a tradition which Pausanias recorded in Troezen (Argolis), the Pythian games at Delph1 were founded by Diomedes, one of the chief Greek warnors in the Trojan War and commander of eighty ships from Argos and Tiryns (Pausanias, Descr. 2.32.2). Thus, under the early Empire many religious customs and institutions were "explained" with aetiologies which traced their origins back to the initiative of great, preferably divine, founders. In the same manner Christians attributed the orign of the eucharist to Jesus. They did not resort to a person who had lived in times long past, as the gentiles liked to do, but to Jesus because he was the greatest authority they knew.

In sum, it is not necessary to suppose that the story of the Last Supper reached Mark as a tradition connected with the eucharist.

${ }^{17}$ This does not exclude the possibility that Mark 1425 goes back to a pre-Easter word of Jesus and that it was later connected with the scene of the Last Supper, see M de Jonge, God's Final Envoy Early Christology and Jesus' Onvi View of His Mission (Grand Rapids, Mich Eerdmans, 1998), 59-69 
Ultimately, however, this story seems to go back to an aetiology of the eucharist. If so, it is also a testimony to a pre-Markan celebration of the eucharist, a testimony which, together with that of Mark 10:38 and $14 \cdot 36$, can be placed next to that of Paul.

(II) The fourth evangelist was also acquainted with the eucharist. A familiarization with the eucharist is evident in John 6:51c-58. True, with regard to this passage, the vanous exegetes take different positions. (a) Some (like Menken) find here a Christological exposition on Jesus as life-giving bread from heaven. From the perspective of this position, the evangelist uses some eucharistic terms, not in order to clarify the eucharist, but simply to illustrate how, or how intensively, one has to believe in Jesus. The message is that one must absorb Jesus in one's belief just as concretely as one consumes the eucharistic elements in participating in the Lord's Supper. ${ }^{18}$ (b) Others (like Bultmann) think that vv. 51c-58 are a redactionally later development of John's text in which Jesus is indeed spoken of as the eucharistic bread. With this interpretation, the passage would also reveal the redactor's view of the eucharist. ${ }^{19}$ (c) There are yet others who (like Klinghardt) regard vv. 51c-58 only as a continuation and elaboration of the theme of Jesus as the bread from heaven; they find no reference whatsoever to the eucharist. ${ }^{20}$

Position (a) seems to me preferable. The agreements which John's language shows with eucharistic terminology are too striking to be incidental. The term "flesh" (in heu of "body") occurs in a eucharistic context in Ignatius; see, e.g., Phld. 4 (next to "blood") and Smyrn. $7: 1 .^{21}$ It is hard to assume that a phrase like "I give my flesh for the life of the world" (John 6:51) has nothing to do with Jesus' death. It as no less hard to believe that phrases like "Whoever eats my flesh and drunks

\footnotetext{
${ }^{18}$ M J J Menken, "John 6,51c-58 Euchanst or Christology?" Bub 74 (1993) 126

${ }^{19} \mathrm{R}$ Bultmann, Das Evangelum des Johannes (12th ed, KEK, Gottingen Vandenhoeck \& Ruprecht, 1952), 174-77, P N Anderson, The Christology of the Fourth Gospel Its Unity and Disunity in the Light of John 6 (Tubingen Mohr, 19961997), 110-36 Some exegetes in this category adnut the possibility that the redactor is the evangelist himself, see, e $\mathrm{g}, \mathrm{R}$ Schnackenburg, Das Johannesevangelum (4 vols, HTKNT 4, Freıburg Herder, 1967-1984), 2 83-96

${ }^{20}$ Klinghardt, Gemeinschaftsmiahl und Mahlgememschaft, 438-40

${ }^{21}$ Ign Rom 73 mentions "the flesh (sarx) of Jesus Chrast" and "his blood" as the heavenly food and dnnk which the martyr hopes to enjoy after his death But it is unclear whether he hopes (a) to be unted wath Jesus' person, or (b) to enjoy a heavenly meal Yet, even in the former case the terminology Ignatius uses herc is eucharistic
} 
my blood ..." (John 6:54, 56) and "My flesh is real food; my blood is real drınk" (John 6:55) have nothing to do with the Church's nte of the Lord's Supper. What John $51 c-58$ seems to say is that one has to absorb Jesus in one's fath as concretely as one consumes the elements of the eucharist and to take the salvific meaning of Jesus' death seriously. This message need not have an ant1-gnostic intention. Participation in the euchanst serves here as an analogy or image of the true way of believing in Christ. Eucharistic language is used here to describe the Johannine concept of farth in Christ. If this interpretation is correct, then John 6:51c-58 does not shed much light on John's view of the eucharist, but it does show that John used the tradition which interpreted the bread and the wine of the supper as Jesus and the consumption of the elements as a representation of his death, the tradition which was also used by Paul, Mark, and Luke, but not by the Didache.

The view that John was acquainted with the eucharist is probably not confirmed by the passage in which the evangelist relates that a soldier stabbed Jesus' side with a lance. This caused, according to John, the effusion of "blood and water" (19:34). The "blood and water" mentioned in this passage seem to symbolize the living streams which flow out from Jesus and by which men are quickened (cf. 7:37-38). There is little reason to assume that "blood and water" refer also to the sacraments here, that is to say, the euchanst and baptism ${ }^{22}$

It remains true, however, that John $6: 51 \mathrm{c}-58$ probably shows that John was acquainted with the rite of the Lord's Supper.

(III) Did 9-10 describes basically the same rite as the one we encountered in Corinth. The agreements are clear. Both meals are a community supper on Sunday evening (Did. 14:1). Both comprise: (a) Benedictions over cup and bread. (b) A real supper (c) A concluding benediction, possibly followed by (d) a session in which prophecies, instruction, admonitions, reprimands, ecstatic utterances, etc. were communicated. It has to be granted, however, that Didache 9-10 does not mention the last part (d) explicitly At any rate, $106 \mathrm{a}-\mathrm{b}$ ("Let grace draw near, let this present world pass away") does not provide a solid basis for the supposition that such an after-supper

22 Pace, e g, R E Brown, The Gospel according to John (2 vols, AB 29(A), London Chapman, 1970), 2 951-52, and C K Barrett, The Gospel according to St John (2nd ed, London S P C K , 1978), 557 Brown abandoned his view that John 1934 refers to the sacraments 11 his The Death of the Messiah (New York Doubleday, 1994), 117082 Here he records it only as an interpretation of some Church fathers 
meeting took place..$^{23}$ Other chapters of the Didache make mention of quite an amount of oral communication which occurred within the community (for instance, 4:3 attempts to make peace between those who are at variance, reproval of members of the community, 11 1-2 instruction, 11.7 speeches delivered by prophets, 11:12 exhortation by prophets, 15:3 mutual reproval among members of the community). It is natural to postulate a social context in which this communication, or at least a great part of $1 \mathrm{t}$, could take place. A session following the Lord's Supper, then, is an obvious option ${ }^{24}$ But while there is every possibility that an after-supper session was the practice, there is no clear evidence for this practice in the text of the Didache.

In my view, Did. 14 refers to the same meal as ch $9-10$, the weekly communty supper on Sunday evening. It simply adds the requirement that before celebrating the Lord's Supper the participants should confess their faults in order to avo1d any profanation of the sacrament. The word "sacrifice" (thysia) used in 14:2 does not characterize the eucharistic meal as a sacrifice; it refers to the eucharistic prayers as thankofferings. ${ }^{25}$ In order to prevent these spiritual thankoffermgs from being impure, those who intend to participate in the eucharist have to confess their sins.

The supper pictured by the Didache is both a real and a sacramental meal. Through their participation in this meal, the members of the community participate proleptically in the eschatological kingdom of Jesus, which is the new shape of the kingdom of David (92) The function of the meal is still the bringing about of the unity of the congregation In this case, however, the unity is not founded in the death of Jesus (as in Paul), but in the fact that the bread that is broken at the beginning of the meal, "once dispersed over the hills, was brought together and became one loaf." In eating from this loaf, the congregation becomes one. Similar ideas occur in blessings which are

${ }^{23}$ Contra Klinghardt, Gemeinschaftsmahl und Mahlgememschaft, 389, who surmuses that "Let grace draw near" and "Let this world pass away" (10 6a-b) are the opening lines of hymns that were sung durnng the meeting after supper

${ }^{24}$ Although members of the communty met also on other occasions, as appears from 42

${ }^{25} \mathrm{~J}$ Behm, "thyo," TWNT 3 189, K Wengst, Didache (Apostellehre), Barnabasbref, Zivetter Klemerisbrief, Schrift an Diognet (Darmstadt Wissenschaftliche Buchgesellschaft, 1984), 53-5 The view of prayers as spintual offerngs became widespread in the Hellenistic and Roman penods, in pagan as well as Jewish and Chnstian curcles See, e g, Jub 222, Rev 83-4, 1 Clem 402-4, 36 1, 44 4, Ign Eph 52, Phld 4, Herm Mand $1032-3$, Const Ap 7332 , Corp herm 131 (Poimandres) For the view of the eucharistic prayers as offenngs, see also Justm, Dial 1171 
pronounced over the bread at the beginning of Jewish meals, as is wellknown.

In its form and function the supper described in Didache is related to that in 1 Corinthians, but the interpretation of the meal is different in so far as Didache does not connect the sacramental significance of the meal with the death of Jesus. But Did. 9-10 is far from being the only specimen of an early Christian eucharist in which references to Jesus' death, his body and blood, and his institution of the nte are lacking. Other instances are (1) the earliest traceable form of the Anaphora of Serapion, ${ }^{26}$ (2) Acta Johannis chs $109-10,{ }^{27}$ (3) Acta Johannis chs. 85-86, ${ }^{28}$ (4) the East-Syrian Anaphora of Addat and Man, ${ }^{29}$ and (5) the Egyptian Anaphora of Mark in the early recension of Papyrus Strasbourg gr. 254. ${ }^{30}$

\section{Age and Orgin of the Lord's Supper}

The basic pattern of the Lord's Supper, according to Paul, was twofold. It consisted of (1) the meal proper, concluded with a prayer of thanks, and (2) a session after the meal. In other words, the detpnon was followed by an assembly in which oral contributions and hymns were exchanged. At the very least, the Didache does not contradict this pattern, and, as I remarked before, it may possibly even confirm it. The same twofold pattern is indirectly attested by Mark. His account of the Last Supper undoubtedly reflects the tradition of the weekly community meal of the Christians According to the description of the Last Supper given in Mark 14.22-26a, the meal proper was followed by a session in which hymns were sung. ${ }^{31}$ The twofold structure of the early Christian community meal is confirmed by Luke's story about a supper shared by Paul and the Christian congregation at Troas (Acts 20.11) According to Luke, this meal took place on a Sunday

${ }^{26} \mathrm{H}$ Lietzmann, Messe und Herrenmahl (Bonn Marcus \& Weber 1926), 186-87, esp 196

${ }^{27}$ C Tischendorf, R A Lipsius and M Bonnet, eds, Acta Apostolorum Apocrypha (2 vols, Leipzig Mendelsohn, 1891-1903), 2 207-9

${ }^{28}$ Tischendorf, Lipsius and Bonnet, eds, Acta Apostolorum Apocrypha, 2193

${ }^{29} \mathrm{~W}$ Macomber, "The Oldest Known Text of the Anaphora of the Apostles Addar and Marn," OCP 31 (1966) 335-71, Rouwhorst, De venng van de ewchanstie in de vroege kerk, 20-21

${ }^{30}$ A Haggi and I Pahl, Prex eucharistica (SpicFn 12, Fribourg, Switzerland Editions Universitarres, 1968), 101-27, Rouwhorst, De vienng van de euchanstie, 22-3

${ }^{31}$ Mark does not say which songs or hymns were sung Hippolytus, Traditio apostolica 25, describes a Sunday evening euchanst during which one or more psalms of the Hallel (Pss 115-118) were sung In this case, the choice had no specific connection with Easter, let alone with Passover 
evening ${ }^{32}$ Owing to certain circumstances it could not begin until midnight When the meal was over, the meeting did not break up A session followed in which there was "much conversation, which lasted until dawn "The same twofold pattern is still attested by Tertullian, Apol 39 16-19 (197 CE, Carthage), who describes the weekly community meal ${ }^{33}$ as consisting of a supper (cena, 39 16) and an aftersupper session devoted to the singing of hymns, both taken from the Scriptures and new compositions, and prayer (39 18-19)

The pattern at issue conforms to that of the normal Hellenistic communal supper, which consisted of a meal (syssition, that 1s, a common meal) and an ensung sympostum ${ }^{34}$ Such suppers were held periodically in all sorts of clubs, societies, associations, religious guilds, and other groups, in which the members wanted to give shape to their ideal of unity, community, equality, and brotherhood (kononia) ${ }^{35}$

\footnotetext{
${ }^{32}$ Luke says "On the first day of the week" (Acts 20 7) This is sometimes taken to mean "On the Saturday mght", thus, eg, the New English Bible But Luke's expression is more likely to mean "On the Sunday" $1 \mathrm{e}$, on the new day following sunnse after Saturday night (thus, e g, E Haenchen, ad loc) In fact, Luke uses the same expression ("on the first day of the week") in Luke 241 to designate the time it which the women went to Jesus' tomb, no doubt after sunnse, and then places the breaking of the bread at Emmaus "on that same day" (Luke 24 13) So Luke has no problem in regarding an evening as part of the preceding day Consequently, Acts 207-11 probably means to say that the breaknng of the bread at Troas took place dunng the night of Sunday to Monday

${ }^{33}$ Designated by Tertullian as cena nostra (39 16), agape (39 16, as in Jude 12), and convivium (39 18)

${ }^{34}$ On this bipartite structure of the banquet in the Hellenistic world, see Ferguson, Backgrounds of Early Chnstranity, 98, Klinghardt, Gemeinschaftsmahl und Mahlgemeinschaft 99-129 Cf footnote 14 above

${ }^{35}$ In the Graeco-Roman world, clubs and voluntary associations of many sorts prohferated enormously Their primary goal was fellowship They intended to unite in a common religious and social expenence different elements of the population, men and women, slaves and free, c1tizens and aliens, Greeks and non-Greeks They were called thiasoi, synodot, koina, hetaireiai, synagogai, komonia, collegia, corpora, sodalitates, etc In these clubs people tried to find the equality, fellowship, and community (komonia, communitas) which society as a whole could not give them Here the humbler members found some compensation for the lack of social recognition which was their part outside the club The common feature of all clubs and associations was that their members dined together on certain occasions See E Ziebarth, Das griechische Vereinswesen (PFJG 34, Leipzig Hirzel, 1896, repr Wiesbaden Martin Sandig, 1969), F Poland, Geschichte des gnechischen Vereinswesens (PFJG 38, Leipzig Teubner, 1909), J S Kloppenborg and S G Wilson, eds, Voluntary Associations in the Graeco Roman World (London Routledge, 1996), on association meals, see 65 F W Dânker, "Associations, Clubs, Thiaso1," ABD 1 501-3, Meeks, The First Urban Christians, 3132, 77-80, Ferguson, Backgrounds of Early Chnstianty, 131-36, M N Tod and S Hornblower, "clubs, Greek," and G H Stevenson and A W Lintott, "Clubs,
} 
Among gentiles, examples of such periodical, communal suppers are numerous. ${ }^{36}$ Cases in point are the suppers which were held six times each year by the association of worshippers of Diana and Antinous at Lanuvium, some 70 kilometers south-east of Rome (second century C.E. $)^{37}$ and the monthly banquets held by an association dedicated to Zeus Hypsistos which are attested in an Egyptian papyrus of about 60 B.C.E. ${ }^{38}$ Jewish examples include the Pentecost feast of the Therapeutae, also called Pannychis, and described by Philo (Contempl 66-90). According to Philo, the Therapeutae came together to share a common supper in their celebration of Pannychis (66-82). After this supper the all-night vigil of Pannychis began: a festival during which the participants formed choirs, sang sacred songs, performed dances, and were in a "sober drunkenness" unt1l sunnse (83-90). Another possible Jewish example of a Hellenistic community supper is the meal of the congregation for which the Community Rule of Qumran gives directions (1QS VI, 2-13): "(a) They shall eat in common and pray in common, and (b) they shall deliberate in common." The former part was introduced by blessings over the bread and the wine (VI, 5-6). The latter part comprised, among other aspects, the study and discussion of the Law (VI, 6-13). ${ }^{39}$ Further instances of common meals held by Jews are the syndeipna mentioned by Julius Caesar in a letter to the magistrates of Parium, a place on the coast of the Troad, east of the Hellespont. Caesar decrees that the magistrates of Parium permit the Jews of their town "to collect money for common meals (syndeipna) and sacred rites." According to Caesar, the Jews were allowed to collect money and to hold common suppers even in Rome (Josephus, Ant. 14.214-16). While it is clear that Caesar is referring here to periodical suppers held by Jews, it is not clear whether these suppers in

Roman," OCD 3 351-53, A Baumgarten, "Graeco-Roman Voluntary Associations and Ancient Jewish Sects," in Jews in a Graeco-Roman World (ed M Goodman, Oxford Clarendon Press, 1988), 93-111

${ }^{36} \mathrm{H}-\mathrm{J}$ Klauck, Herrenmahl und hellenistischer Kult (2nd ed, NTAbh NF 15, Munster Aschendorff, 1982), 68-71, Klnghardt, Gemeinschaftsmahl und Mahlgememschaft, 33-43, 55-56

${ }^{37} \mathrm{H}$ Dessau, Inscriptiones latinae selectae (5 vols, Berlin Weidmann, 1892-1916), vol 2, no 7212, discussed by Klauck, Herrenmahl und hellenistischer Kult, 70, and R L Wilken, The Christians as the Romans Saw Them (New Haven Yale University Press, 1984), 36-39

${ }^{38}$ PLond $2710=$ F Pressigke et al, eds, Sammelbuch grechischer Urkunden aus Agypten (6 vols, Strassbourg: Trubner, 1915), vol 2, no 7835, discussed by Klauck, Herrenmahl und hellenistscher Kult, 70

${ }^{39}$ The same injunctions are given in 1QSa II, 17-21 
Paruum and Rome were events which took place weekly, monthly, yearly, or whatever.

For a weekly, communal deipnon, as attested by Paul and the Didache, there is no pre-70 Jewish analogy. There are only remote parallels, such as the weekly sabbath meal held by the Therapeutae (Philo, Contempl 30-33). Philo reports that the Therapeutae held their cultic assembly on the sabbath. At this gathering, the most qualified members of the group delivered an allocution. Subsequently, after sunset, those present shared a common supper. In this case, however, the order of the events is precisely the opposite of that of the Lord's Supper. For in the latter case, the supper was not preceded, but followed by the meeting of the community. The ordinary order, namely, (1) supper, and (2) meeting, is attested by 1QS VI, 2-13 and 1QSa II, 17-21 (see above), but it is not clear with which frequency these meals and meetings took place.

Furthermore, there is solid evidence for the existence of weekly meetings of Jews in their proseuchae or synagogues for the study of the Law (e.g., Philo, Mos 2.215-16; cf. Spec. 2.62-63; Acts 13:14-15). ${ }^{40}$ However, these synagogal meetıngs on sabbath were not followed by a common meal. Philo states that on sabbath, Jews used to study the Law "almost up to the late afternoon," but then went home. This is the description of sabbath worship provided by Philo:

Moses required them [1 e., the Jews] to assemble in the same place on these seventh days, and sitting together in a respectful and orderly manner hear the laws read so that none should be 1gnorant of them And indeed they do always assemble and sit together, most of them in silence except when it is the practice to add something to signify approval of what is read But some prest who is present or one of the elders reads the holy laws to them and expounds them point by point till about the late afternoon, when they depart having ganed both expert knowledge of the holy laws and considerable advance in prety ${ }^{41}$

Something similar is attested by Agatharchides (quoted by Josephus, Ag Ap 1210), who reports that Jews on sabbath meet in their sacred places (hiera) until the evening (mechn tes hesperas). Josephus himself, too, affirms that Moses ordaned that every week Jewish men "should desert their other occupations and assemble to listen to the Law and to

${ }^{40}$ Cf A Kasher, "Synagogues as 'Houses of Prayer' and 'Holy Places' in the Jewrsh Communities of Hellenistic and Roman Egypt," in Ancient Synagogies Histoncal Analysis E Archaeological Discovery (ed D Uman and P V M Flesher, 2 vols, StPB 47, Leiden Brill, 1995), 1 205-20, see 211-12

${ }^{41}$ Philo, Hypothetica, apud Eusebius, Praep ev 87 12-13 
obtain a thorough and accurate knowledge of it" (Ag. Ap. 2.175).$^{42} \mathrm{But}$ none of these testimonies says that the synagogal study of the Law on sabbath was concluded by a common supper.

Archeological evidence concerning ancient synagogues shows that several ancient synagogues contained rooms where food could be prepared for meals, or rooms where meals could be served. But all this evidence is second century C.E. (Ostia) or later (third century: Stobi in Macedonia $)^{43}$ and in any case it does not prove that, if communal meals took place in synagogues, they took place every week or every sabbath.

Consequently, the Lord's Supper cannot be traced back to any specific Jewish custom, neither to a meal nor to an assembly. The periodical supper held by voluntary associations was a generally Hellenistic practice. This practice was shared by pagans and Jews alike. In this respect pagans and Jews shared the same cultural tradition. It is impossible, therefore, to differentiate between periodical community suppers held by pagans and similar suppers held by Jews. Consequently, it is impossible and pointless to derive the Christian community supper from a specifically Jewish meal. Rather, the Christian community supper is a specimen, alongside many similar specimens which were practiced by pagans as well as Jews, of the generally Hellenistic phenomenon of the periodical community supper. The bipartite agenda of the Christian supper, consisting of (a) the deipnon, and (b) the

${ }^{42}$ See also Philo, Creation 128: Moses ordained the Jews "to keep a seventh day holy, abstaining from other work that has to do with seeking and gaining a livelihood, and giving their time to the one sole object of philosophy [i.e., the Law] with a view to the improvement of character and submission to the scrutiny of conscience" (Philo, On the Creation of the World [trans. F. H. Colson and G. H. Whitaker; LCL; Cambridge: Harvard University Press, 1929-1962]); Josephus, Ant. 16.44: "We give every seventh day over to the study of our customs and law," in a speech of Nicolas of Damascus to Agrippa on behalf of the Jews of Ionia, ca. 14 B.C.E. (Flavius Josephus, The Jewish Antiquities, Books 1-19 [trans. H. St. J. Thackeray et al.; LCL: Cambridge: Harvard University Press, 1930-1965]). Josephus, Vita 279, relates that a synagogal meeting on sabbath was sojourned at "the sixth hour" (i.e., at noon) "at which it is our custom on the sabbath to take our midday meal." The verb used here by Josephus, aristopoieisthai, refers to luncheon, not to supper. But Josephus does make it clear that Jews used to take lunch on sabbath at home, not in the synagogue.

${ }^{43}$ L. V. Rutgers, The Hidden Heritage of Diaspora Judaism (2nd ed.; CBET 20; Leuven: Peeters, 1998), 117; somewhat more optimistically R. E. Oster, "Supposed Anachronism in Luke-Acts' Use of synagoge: A Rejoinder to H. C. Kee," NTS 39 (1993): 178-208, see 200. But even Oster adduces no evidence for synagogal suppers which took place every week. 
ensuing meeting, shows that it is generally Hellenistic in character. ${ }^{44}$ At most one can say that this Christian variant of the Hellenistic community supper betrays some Jewish influence, namely, its weekly repetition and its introductory prayers. Its weekly repetition must have been taken over from the Jewish custom to meet on the Sabbath for the study of the Scruptures. The practice of "saying grace" before a meal was a typically and exclusively Jewish custom..$^{45}$ That does not alter the fact, however, that the Lord's Supper orignated as a Christian form of the generally Hellenistic phenomenon of the periodical supper held by voluntary associations.

Why did the Lord's Supper take place on Sunday? The answer to this question can be kept very simple. On Saturday evening many early Christians, all or most of them Jews, already had other obligations. In fact, on Saturday evening many Jewish households assembled for supper. ${ }^{46}$ Therefore, Christian Jews had to choose another evening for the supper of their community. They chose the earliest possible opportunity: Sunday evening, after working hours, for until the time of Constantine the Sunday was a working day. The association of Sunday with Jesus' resurrection is at any rate late and secondary. This association is not attested untıl Ignatius (Magn. 9:1) and Barnabas (15:9; then also Justin, 1 Apol 67.8). ${ }^{47}$

${ }^{44} \mathrm{Cf} \mathrm{H}-\mathrm{J}$ Klauck, "Lord's Supper," $A B D 4362-72$, esp 370 on pagan suppers followed by social parties "The sequence of [a] the main meal, including a dnnk offering for the gods, [and b] philosophical discussions, musical-artistic presentations, speeches and songs at a symposium, could provide a structural equivalent to a church's celebration with [a] a meal (1 Cor 11 20-21) eucharistic double action (1 Cor 10 16-17), [and b] worship in word with prophecy, glossolalia, the reading of scripture, interpretation, psalins, songs and prayers (1 Cor 14)" (1talics and square brackets mme, de J)

${ }^{45}$ Jos Asen 85 , Sib Or 426, of 1QS VI, 4-5 and Josephus on the Essenes, BJ 2131 "The priest says grace before the meal, to taste the food before this prayer is forbidden ( ) for at beginning and end they give thanks to God as the giver of life " The prayer pronounced at the beginning of Jewish meals, however, can be considered the counterpart of the libation which often preceded suppers among the gentiles Such libations were performed, e $g$, at the banquets of the society devoted to Diana and Antınous in Lanuvium (see $n$ 37) and at the monthly banquets of the society of Zeus Hypsistos attested in PLond 2710 (see $n$ 38) Epictetus admonishes his pupils to be grateful to God "for life itself and for what is conducive to 1 , for dry fruits, for wine, for olive oil, give thanks to God (encharistel tor theor) "But Epictetus does not instruct them to give expression to this gratitude in prayers at the beginning of meals

${ }^{46}$ See, e g, Phulo, Contempl 36-37, 73, John 12 2, of v 12

${ }^{47}$ It is of course true that Mark 161 and the other gospels situate the resurrection of Jesus "on the first day of the week" But firstly, saying that "Jesus has risen on the first day of the week" is not the same thing as sayıng that "the first day of every week is the day of Jesus' resurrection "Secondly, the former is an histoncal statement, the 
Did the Lord's Supper ornginate before or after Jesus' death? The tradition concerning the institution of the Lord's Supper by Jesus himself during the Last Supper is most likely a post-Easter aetiology, as I argued before. In theory, this does not rule out the possibility that, at places, people who acclaimed Jesus' 1deas began to assemble and to share a common supper on Sunday evening already during his lifetıme. One might be tempted to regard this possibility as likely, for it would allow the reconstruction of the history of the eucharist to be a gradual, progressive development, running from before to after the death of Jesus The Didache-type of eucharist, in which any reference to Jesus' death is lacking, could then perhaps be construed as pre-Easter. However, it must be stressed that there is not the slightest evidence for such an assumption. Rather, there is strong evidence to the contrary. In fact, all early Christian witnesses of the weekly celebration of the Lord's Supper agree that it was celebrated on Sunday evening. No early source places the weekly supper on another evening of the week. This may be an indication that the history of the Lord's Supper goes back to the practice of one single group of Jewish followers of Jesus who remained faithful to him after his death. For while it is conceivable that several groups of Jesus' followers began to assemble weekly already during his lifetime, it is most unlikely that all these preEaster groups did so on Sunday. As a consequence, if after Jesus' death all Christian groups turn out to have therr weekly assembly on Sunday, this practice is likely to derive from the practice of one single group. Otherwise it is incomprehensible why all post-Easter groups which met weekly did so on Sunday evening: they could have held their supper, and contınued to hold it, on any evening of the week except Saturday evening. If this line of reasoning is correct, the group from which the custom of a weekly supper on Sunday evening passed to other groups was probably a post-Easter group of Christian Jews. For only a group of people who were convinced that Jesus, although he had been killed, was not dead but alive, that is, restored to life by God, - only such a group can have been vital enough to entice other people

latter a liturgical one It is quite a distance to come from the one to the other Thirdly, 1t is by no means certain that the phrase "on the first day of the week" in Mark 161 and its parallels reflect the Chnstian calendar, not the Jewish Fourthly, the "first day of the week" in Mark 161 may simply be the result of Mark's calculation of the third day after the day of Jesus' death, given the early Christian tradition that Jesus' resurrection took place "on the third day, according to the Scriptures" (1 Cor 15 4, cf Mark 831 , 931,1034 ) and his death on a Frday (Mark 1542 ) 
to take over its custom to hold a weekly supper on Sunday evening. But then the Lord's Supper must be of post-Easter origin.

\section{Later Developments}

The evidence for the history of the eucharist in the second and third centuries is too scanty to allow for a satisfying, representative reconstruction. One must not perceive this history as following a linear development; considerable latitude should be allowed for regional differences. In general, however, the following stages can be distinguished.

(a) Alongside the supper held on Sunday evening, a cultic assembly began to be held on Sunday morning before dawn. We learn from the younger Pliny, Roman governor of Bithynia in Asia Minor from 111 to 113 C.E., that the Christians in that area "met regularly before dawn (ante lucem) on a fixed day to chant verses alternately amongst themselves in honor of Christ, as if to a god (. . .). After this ceremony it was their custom to disperse and reassemble later to take food of an ordinary, harmless kind" (Pliny, Ep. 10.96). Since the Christians are said to reassemble at the end of the day in order to have a common supper, the "fixed day" on which the morning office took place was probably also the Sunday.

This early morning meeting held by the Chnstians of Bithynia can be considered an analogy to the morning prayer of the Essenes who, according to Josephus (B.J. 2.128-29), assembled "before sunnse and offered the Deity some traditional prayers as if beseeching him to appear." ${ }_{48}$ After this the Essenes went to work. In the evening they

${ }^{48}$ For another example of a communal prayer before sunnse, see Philo's account of the festival of Pannychis celebrated by the Therapeutae, Contempl 89 At the end of the night in which they celebrate this festival, that is, at dawn, "they stand with their faces and whole body turned to the east and when they see the sun rising they stretch their hands up to heaven and pray for bnght days and knowledge of the truth and the power of keen sighted thinking And after the prayers they depart each to his private sanctuary "This morning prayer, however, is the communal variant of the morning prayer which each of the Therapeutae prayed individually every morning at sunrise, tbid 27 The texts of several morning prayers pronounced "at the rising of the sun" are preserved in 4Q503, see F García Martínez and E J Tigchelaar, The Dead Sen Scrolls Study Edition (2 vols, Leiden Brill, 1997-1998), 1999-1009 Whereas the communal morning prayer of the Bithyman Christians is a weekly rite, that of the Essenes is daily, that at the end of Pannychus of the Therapeutae yearly, and those of 4Q503 probably monthly Morning prayers at dawn were also performed by gentule religious groups The closest analogy to the Christian prayers at dawn in Bithynia is the morning prayer of the conmunity of Theos Hypsistos at Onoanda in Lycia, attested by the inscription 
reassembled for takıng supper (B.J. 2.132). Thus, the Christians of Bithynia and the Essenes had more or less the same schedule for the day (morning prayer before sunrise, dally work, common supper), except that the Essenes performed this program every day of the week, not only once a week. Moreover, the Essenes also had a common meal at noon.

The Chnstian morning meeting described by Pliny was a service of prayer, singing, and admonition. Later it was also used for instruction (Hippolytus, Traditio apostolica [Rome, ca. 215 c.E.], chs. 35 and 39).

In the second century, the supper on Sunday evenung contunued to be both a sacramental and a real meal. People participated in it "ad Capiendum cibum" (Pliny, Ep. 10.96). Justin speaks of the meal as consisting of "food dry and liquid" (Dial. 117.3). According to the same author, it was a communal meal, consequently an evening meal, but preceded by a service of lessons, admonition, and prayer (1 Apol. 67.3-8; analogy: the sabbath meal of the Therapeutae). About 200 C.E., Tertullian stresses the chantable function of the Christian supper. ${ }^{49}$ The meal still conformed to the two-fold pattern of (a) the common meal proper (syssition), plus (b) the religio-social gathenng, including the singing of scriptural or self-made hymns, and concluded by prayer.

(b) In the course of the second century, morning services (such as recorded by Pliny as taking place on Sundays) began also to be held on other days of the week. ${ }^{50}$ Subsequently, the celebration of the euchanst came to be introduced in these morning services, probably first on the Christian fast days, that 1s, on Wednesday and Friday, ${ }^{51}$ although the non-eucharistic assemblies, devoted to lessons, admonition, and prayer,

SEG 933 (3d century C E), on which see S Mitchell, "The Cult of Theos Hypsistos," in Pagan Monothersm in Late Antiquity (ed P Athanassiadi and M Frede, Oxford Clarendon Press 1999), A1-148

${ }^{49}$ See Tertullian, Apol $3916-9$, where he speaks of the agape of the communty as cena nostra and convivum, at which people discumbunt and saturantur

${ }^{50}$ Hippolytus, Traditio apostolica 35 and 39 These dally services took place sometime early in the morning before work The growing number of morning services, first without and then with the celebration of the eucharist, mirrors the desire formulated by the author of the Didache "Frequent the company of the saints datly, so as to be edified by their conversation" (4 2) and "Come often together for spintual improvement" (16 2)

51 Tertullian, De oratione (dated to 198-204 C E) 19 1-4 "Statio solvenda accepto corpore Dommn," that is, "1n receiving the body of the Lord they have to break the fast" Thus passage shows that in North-Afnca about $200 \mathrm{CE}$ certain people celebrated the eucharist on fast days, that $1 \mathrm{~s}$, on other days than Sundays, probably on Wednesdays and Fndays (Did 81 ), early in the morning 
continued to be held on the same days next to the eucharistic morning services. The introduction of the eucharist in the morning services occurred not later than the end of the second century Obviously, many Christians felt that one eucharist a week was not enough. Out of sheer desire for the community with the Lord and fellow Christians, they began to celebrate it twice or more times a week early in the morning. Hippolytus' Traditio apostolica records eucharistic services on all days of the week (nncluding Sundays), before working hours ${ }^{52}$ The food distributed in the morning service could of course be much less substantial than that in the Supper held on Sunday evening. Therefore, it was probably no longer necessary for those who wanted to participate in this morning eucharist to bring their own food. In this morning assembly the wine was often replaced by water. ${ }^{53}$ There was probably netther time nor space to eat and drink reclining on couches. As a result, the eucharist of the Sunday morning could easily become a more ritualistic, and a less "ordinary," meal.

Meanwhile, the community supper continued to be held, as both a "real" and a sacramental meal, on Sunday evening. For Tertullian (Apol. 39), the main community meal was stll on Sunday evening. It was a real supper for all members of the community.

(c) From the eucharistic morning services on other days of the week than Sundays, the celebration of the eucharist-as mentioned abovepenetrated into the Sunday morning service, that is, the ceremony recorded for the first time by Pliny. This changed the character of both

${ }^{52}$ Chs 22 and 36 From ch 25 "He [the bishop] should not say "sursum corda," for that is sald in the morning euchanst [anaphorn, oblatio]," it can probably be gathered that a euchanst at dawn took also place on Sunday, next to the Sunday evenung ceremones which evolved out of the traditional Lord's Supper, namely, the social kynakon deipnon ( $=$ the eulogia, ch 26-28), and the lucernarium, a euchanst introduced by a benediction over the lamp (ch 25)

${ }^{53}$ Thus was the case, for instance, at Smyrna about $250 \mathrm{C} \mathrm{E}$, see Martyrdom of Pionuus ch 3 " and after they had prayed and taken the sacred bread with water ", H Musurllo, ed, The Acts of the Christian Martyrs (OECT, Oxford Clarendon Press, 1972), 136-37 About the same time Cyprian, bishop of Carthage, felt compelled to take action against the use of water in heu of wine in the early morming meetings in Carthage This is the issue of his Ep 63 In the second century the Ebionites and Tatian are on record as having used water instead of wine, see Epiphanius, Pananon 3016 and 46 About 200 Clement of Alexandra, Str I, 19, 961 , expressed his disapproval of certain heretics who used water instead of wine in the euchanst, see $\mathrm{O}$ Stahlin and L Fruchtel, eds, Stromata I-IV (vol 2 of Clemens Alexandnnus, ed O Stahlin and L Fruchtel, 3d ed, GCS 52 (15), Berlin Akademe-Verlag, 1960), $6126-$ 621 Later these heretıcs were labeled Aquarians, see ODCC ( $3 \mathrm{~d}$ ed, Oxford Oxford Unversity Press, 1997), 94 
this Sunday morning service and the Sunday evening service. As to the morning service, from a service of prayer, singing, and instruction, it became a symbolic and sacramental meal. Of the two meals that were now held in the Christian community on Sunday, the symbolic meal that took place in the morning gradually became more important than the real meal held in the evening. The reason for this was that the Sunday morning rite was destined for "the whole community" (Hippolytus, Traditio apostolica 22), whereas the supper was destined for, or at least attended by, those who needed support. For Tertullian, the Sunday evening meal was still intended for all members of the community. Hippolytus, however, describes the evening meal as attended, not by the whole community, but by only a number of the members of the community ("those faithful who are present," ch. 26). The community as a whole participated in the eucharist celebrated on Sunday morning (ch. 22). Thus, a distinction developed between the more important service held on Sunday morning, attended (in principle) by the whole community, and the supper that continued to be held as a charity meal on Sunday evening. The difference in status between the two ceremonies is already reflected in the terminology Hippolytus uses for each of them. He refers to the assembly of the whole community as the "eucharist" (eucharistia) and to the supper as a "eulogy" (eulogia, ch. 26, 28) or benediction. In contradistinction to the food consumed in the eucharist, the bread of the Sunday supper is "not the sign of the body of the Lord" (ch. 26).

In the middle of the third century, Cyprian makes some observations on the difference between the two Sunday meals of the Christian community, that is, the eucharist celebrated early in the morning (mane) and the agape (cena, convivium nostrum) held in the evening. The difference is that at the eucharist, the community as a whole (plebs, omnis fraternitas) is present, whereas for logistic reasons the supper is only attended by part of the community, obviously by the poorer members of the community. Because of this Cyprian can say: " 'The true sacrament' is the one we celebrate in the presence of the entire congregation." ${ }^{44}$ Here we see how the eucharistic ritual of the Sunday morning is upgraded as the main sacrament of the Christian

${ }^{54}$ Cyprian, Ep. 63.16: "Cum cenamus, ad convivium nostrum plebem convocare non possumus, ut sacramenti veritatem fraternitate omni praesente celebremus," that is, "when we have supper, we cannot invite the whole congregation to our common meal, with the result that the true sacrament is the one we celebrate in the presence of the whole congregation (i.e., the eucharist celebrated in the morning)." See Klinghardt, Gemeinschaftsmahl und Mahlgemeinschaft, 516-17. 
Sunday, while the Sunday evening meal, which was originally the most important assembly of the Christian community, is devaluated. Cyprian does not yet say that the supper is not a sacrament. Thus, one cannot say that, according to Cyprian, the agape was divested of its sacramental character. But it is clear that for Cyprian the eucharist, celebrated early in the morning, is a more important sacrament than the agape. The reason for this shift in the assessment of the two ceremonies is simply that the eucharist was the sacrament in which the whole of the community took part, whereas in the agape only part of the community participated, and the less well-to-do part at that.

At the same time Cyprian makes it clear that the differentiation in status between eucharist and agape was occasioned by the growth of the congregation: "When we have supper, we cannot invite the whole congregation." 55 In some places, the agape continued to be held until the seventh century. ${ }^{56}$

\section{Conclusions}

1. In reconstructing the earliest history of the Lord's Supper, 1 Corinthians and Didache should and can be used as the main sources; they are mutually independent witnesses of a common, earlier tradition.

2. Originally, the Lord's Supper conformed to the bipartite pattern of the periodical Hellenistic group supper. This periodical Hellenistic group supper was practiced by gentile as well as Jewish societies. It consisted of two parts: (a) the first part was the deipnon or syssition proper, that is, a common supper; this was concluded by a short religious ceremony; for example, the drinking of a cup with a libation, grace, and a song of praise. (b) The second part of the Hellenistic group supper was a gathering in which the participants remained reclined on their couches and entertained each other with all sorts of speeches, songs, recitations of literary compositions, and other amusement. This two-fold pattern is still discernible in Paul's account of the Lord's Supper in 1 Cor 11:17-14:40, Acts 20:11, and Tertullian Apol. 39.16-19. It is also reflected in Mark 14:22-26a.

3. The Lord's Supper originated as the post-Easter Christian equivalent of the periodical Hellenistic community meal, that is, the periodical

\footnotetext{
${ }^{55}$ Cyprian, Ep. 63.16: "Cum cenamus, ad convivium nostrum plebem convocare non possumus."

${ }^{56}$ Trullan Synod, canon 74 (692 C.E.).
} 
supper held by clubs, societies, cultic associatıons, religious groups, guilds, et cetera. $^{57}$ Apart from the twofold pattern, the weekly community supper of the Christians and the periodical supper of Hellenistic associations also parallel each other in that in both instances participants were supposed to bring their food with them With regard to the practice of having periodical society suppers, there is no distinction between gentiles and Jews Both groups shared the general, Hellenistic, socio-cultural tradition on that point In the matter of periodical society suppers, gentiles and Jews did not behave differently. It is impossible, therefore, to trace the Christian weekly communal supper exclusively to a Jewish or a gentile tradition. Since periodical society meals are a generally Hellenistic phenomenon, among Jews and gentiles alike, the Christian community meal cannot be connected with a specifically Jewish tradition (nor with a specifically gentile tradition for that matter). The Lord's Supper did not evolve out of a Jewish meal or synagogal assembly. It arose as the Christian analogy to the periodical suppers in which numerous clubs, societies, and religious groups, both Jewish and gentıle, gave shape to their ideals of equality, fellowship, unity, and community. Some features of the Christian supper reveal its rise in a Jewish context; for instance, the fact that it was held weekly, and the custom of pronouncing prayers at the beginning of the meal. Yet the supper of the Christian community cannot be derived from any specific Jewish meal or meeting.

4. Since the Lord's Supper originated as a Chnstian variant of the Hellenistic community meal, its primary function was to establish the fellowship, communion, and unity among the participants. ${ }^{58}$ The interpretation of this unity as the body of Christ, the designation of

\footnotetext{
${ }^{57}$ This is not to say that the Christian congregations of the first century onginated as ordinary pnvate associations Meeks, The First Urban Christians, 78-80, has pointed out the differences Firstly, the Christans' concept of membership was more exclusive than that of other associations Secondly, in their composition the Christian communities were socially more heterogeneous than most other associations Thirdly, the Christrans did not take over the typical temunology which the associations used as titles for their leaders Fourthly, the Christian communities had more, and more intensive, interlocal linkages with other Chnstian communities than was usual among ordinary associations

${ }^{58}$ Both Paul and the Didache stress the mportance of the fact that those who participate in the Lord's Supper eat from one loaf The unty of the bread symbolizes the unity of the Church See 1 Cor 1017 "Because there is one loaf, we, many as we are, are one body, for it is one loaf of which we all partake", Did 94 "As this broken bread, once dispersed over the hulls, was brought together and became one loaf, so may thy Church be brought together from the ends of the earth into thy kingdom "
} 
bread and wine as Jesus' body and blood, and the attribution of the ceremony's origins to an institution by the historical Jesus himself must all be regarded as secondary, theological, Christian rationalizations The prumary idea of the Lord's Supper was that it gave shape to the ideal of unity of the Christian community. Since this unity cannot be achieved in this world, the Lord's Supper displaced the participants for the duration of the meal into another, ideal, utopian reality; namely, that of eschatological perfection. Both in Paul and the Didache the Lord's Supper is an anticipation of the age to come ${ }^{59}$

5 The phenomenon of a euchanst which consisted of a sacramental meal that was not a normal, real and full meal, and which was celebrated on Sunday morning, arose not later than the third century (Cyprian). It did not onginate, as is often believed, from the separation of eucharist and agape.60 Rather, it was the result of four successive developments.

(a) the rise of services of prayer and singing held on Sunday morning before work, ${ }^{61}$

(b) the rise of similar non-eucharistic morning services, mainly intended for prayer, on other days of the week, ${ }^{62}$ probably first on the fast days, Wednesday and Friday, later also on other days,

(c) the introduction of the eucharist into these morning services on weekdays, ${ }^{63}$

(d) the introduction of the eucharist into the morning service of the Sunday, in analogy to the eucharistic services on weekdays Subsequently, the Sunday morning service became more important than the evening service (agape), because the morning service was attended by the congregation as a whole, whereas the evening service (including the

${ }^{59}$ Both for the Cornthians and for Paul the Lord's Supper is a proleptic expenence of the ideal eschatological state This is clear, among other things, from the fact that they interpret ecstatic utterances in the gathering of the congregation as manifestations of the Spint According to Did 91, the wine over which the thanksgiving 1 pronounced is the frut of "the holy Vine of thy servant David," that is, it ts the wine of the mimunent messianic kingdon, which those who participate in the eucharist relish in anticipation According to Hippolytus, Traditio apostolica 21, the eucharist of the newly baptized represents "the promused land flowing with milk and honey"

${ }^{61}$ Thus, for instance, G J M Bartelink, Twee apologeten wit het vroege christendon Justınus en Athenagoras (Na de Schnften 1, Kampen Kok, 1986), 15

${ }^{61}$ Pliny, Ep 10967

${ }^{62}$ Hippolytus, Traditio apostolica 35, 39

${ }^{63}$ Tertullan, De oratione 19 1-4 
supper) attracted only part of the members of the community, and not the most distinguished part.

In short, the Sunday morning eucharist is not a segment of the Sunday supper that broke away from the Lord's Supper and drifted away to the Sunday morning. It is a ceremony that evolved out of the service of prayer and worship held on Sunday morning which is recorded for the first time by Pliny at the beginning of the second century. 